\title{
CD34 IMMUNOEXPRESSION IN PENILE CARCINOMA ${ }^{1}$
}

\author{
Antonio Carlos Pereira Martins ${ }^{2}$ \\ Sérgio Britto ${ }^{3}$ \\ Clécio Takata ${ }^{4}$ \\ Silvio Tucci Jr. ${ }^{5}$ \\ Tiago José Borelli-Bovo ${ }^{6}$ \\ José Anastácio Dias Neto ${ }^{5}$
}

\begin{abstract}
Objective - To investigate microvessel density as a risk factor in squamous cell carcinoma of the penis. Methods - Fifty patients with penile carcinoma were evaluated retrospectively. The mean age and standard deviation were $60.8 \pm 11.8$ years. All of them were treated by penectomy and with positive nodes underwent groin lymphadenectomy. Tumor grading was $36 \mathrm{G} 1$ and 24 G2/3. Primary lesion stage was 22 pT1 and 28 pT2-4. Positive inguinal nodes were observed in 18 patients. Selected paraffin embedded sections were submitted to CD34 immunohistochemical analysis by the avidinbiotin-immunoperoxidase method with antigen retrieval. All slides were examined using an automatic analyzer system and the number of micro-vessels in 10 high magnification power fields $(400 \mathrm{X})$ were counted in a blind analysis. Results - Median number of microvessels was 631 in $\mathrm{G} 1$ versus 695 in G2/3 tumors $(\mathrm{p}=0.78)$, and 696 in $\mathrm{pT} 1$ versus $566 \mathrm{pT} 2-4$ tumors $(\mathrm{p}=0.23)$. The respective data for $\mathrm{pN} 0$ patients was 525 and for $\mathrm{pN}+$ was $696(\mathrm{p}=0.01)$, which is an unexpected result. Conclusion - CD34 immunoexpression or microvessel density determined by this method bear no association with tumor grade, stage or prognosis. Available from URL: http://www.scielo.br/acb
\end{abstract}

Key Words - Penile carcinoma, squamous cell carcinoma of the penis, CD34.

\section{INTRODUCTION}

Penile carcinoma may be cured by inguinal lymphadenectomy ${ }^{1}$. However, management of regio- nal nodes is controversial in patients who present with clinically negative inguinal nodes in whom the primary lesion invades the corpora (pT2-4). Approximately 20\% of patients with non palpable groin nodes will have occult metastases ${ }^{1,2}$. The delayed lymphadenectomy is associated with a higher mortality rate and the prophylactic lymphadenectomy carries morbidity and should be avoided in patients without lymphatic nodes carcinoma. Those who adopt prophylactic inguinal lymphadenectomy rely on conventional risk factors such as tumor grade or local stage, but the number of individuals undergoing unnecessary surgery is about $20 \%$ and these criteria spares surgery in $4 \%$ or more patients with occult metastases ${ }^{1,3}$. Thus, it is important to explore the predictive value of other tumor markers on the outcome of patients with penile carcinoma. In this research we investigate the role of angiogenesis as a risk factor in patients with squamous cell carcinoma of the penis.

\section{METHODS}

Between January of 1976 and December of 1998, 50 patients with the diagnosis of squamous cell carcinoma of the penis treated at our hospital were selected for this study. Inclusion criteria were adequate specimens for histology and immunohistochemistry, and a follow up of 5 years or more. Age range varied from 32 to 86 years (mean $\pm \mathrm{SD}=60.8 \pm 11.8$ years). The tumor was staged retrospectively according to 1999 TNM system ${ }^{4}$. The grading system adopted was that proposed by Broders: differentiated (G1), moderately differenciated $(\mathrm{G} 2)$ and undifferentiated $(\mathrm{G} 3)^{3}$.

\footnotetext{
1 This research was carried out with FAPESP support at HCFMRP-USP.

2 Professor of Urology - FMRP-USP

3 Assistant Professor of Pathology - FMRP-USP

4 Student of Medicine - FMRP-USP

5 Assistant Professor of Urology - FMRP-USP

6 Resident of Urology - HCFMRP-USP
} 
Primary treatment consisted of total (5) or partial (45) penectomy. Approximately 6 weeks after penectomy 10 patients underwent bilateral inguinal lymphadenectomy in consequence of clinically positive groin nodes. The histology confirmed that all of them were $\mathrm{pN}+$. The remaining 36 patients with non palpable groin nodes were followed, of whom 8 required delayed inguinal lymphadenectomy for clinical relapse. Metastasis was confirmed histologically in all 8 cases.

Except for patients who died of disease followup varied from 5 to 22 years (median 9).

Histological slides were revised to select representative areas of the primary lesion, and corresponding formalin fixed, paraffin embedded tissue blocks were sliced for CD34 immunohistochemical analysis. Two $4 \mathrm{~mm}$ blank sections were cut from each designated block. Slices were then mounted on poly-L-lysune coated slides, de-waxed in xylene and rehydrated with graded ethanol to water. Sections were then incubated with 3\% hydrogen peroxide in absolute methanol for 20 minutes. Immunohistochemical reaction was performed by the avidin-biotin-immunoperoxidase method with antigen retrieval ${ }^{5}$ using antibody antiCD34. The immunohistochemical preparations were counterstained with hematoxilin. Slices of a known colon carcinoma and primary antibody replaced by mouse serum were used as positive and negative controls. All slides were examined using an automatic analyzer system (KS-400, Zeiss). Number of microvessels in 10 high magnification power fields (400X) were counted in a blind analysis.

\section{RESULTS}

The association between number of vessels and tumor grade, T stage and metastases is showed in Tables 1,2 and 3.

Table 1 - Relationship between tumor grade and microvessel density.

\begin{tabular}{cccc}
\hline Tumor Grade & N & \multicolumn{2}{c}{ Number of Vessels* } \\
\cline { 3 - 4 } & & Mean \pm SD & Median \\
\hline 1 & 36 & $660 \pm 274$ & 631 \\
$2+3$ & 14 & $683 \pm 195$ & 695 \\
\hline
\end{tabular}

* Two-tailed $\mathrm{P}=0.78$ (unpaired $\mathrm{t}$ test)

Table 2 - Tumor T stage versus CD34 expression.

\begin{tabular}{cccc}
\hline Tumor Stage & N & \multicolumn{2}{c}{ Number of Vessels* } \\
\cline { 3 - 4 } & & Mean \pm SD & Median \\
\hline pT1 & 22 & $709 \pm 245$ & 696 \\
pT2-4 & 28 & $620 \pm 261$ & 566 \\
\hline
\end{tabular}

* Two-tailed $\mathrm{P}$ is 0.23 (unpaired $\mathrm{t}$ test)

Table 3 - Tumor N/M stage versus vessels count.

\begin{tabular}{cccc}
\hline Tumor Stage & N & \multicolumn{2}{c}{ Number of Vessels* } \\
\cline { 3 - 4 } & & Mean \pm SD & Median \\
N0M0 & 32 & $724 \pm 240$ & 696 \\
N/M+ & 18 & $521 \pm 230$ & 525 \\
\hline
\end{tabular}

* Two-tailed $\mathrm{P}$ is 0.01 (unpaired $\mathrm{t}$ test)

\section{DISCUSSION}

The development of solid tumors needs of vascular supply. However, angiogenesis does not depend exclusively on Vascular Endothelium Growth Factor (VEGF) since it can be induced by other proteins of the transmission chain of Ras gene, and influenced by hypoxia ${ }^{6}$. Tissue microvessel density should express the net balance between angiogenesis activation and inhibition. The CD34 protein has been used in the determination of microvessel density because it is expressed in the vascular endothelium and can be detected by immunohistochemistry. However, its association with the prognosis is controversial. For 
instance, a positive correlation was established in ovarian tumors while in non-small cell lung cancer there was a lack of such association ${ }^{7,8}$. On the other side, a positive relationship of microvessel density and prognosis was reported in prostate adenocarcinoma for the endothelial marker CD34 but not for the CD319.

Our data in penile carcinomas show no association between microvessel density (or CD34 immunoexpression) in primary lesion and tumor grading or T staging. Statistical analysis showed association between metastases and microvessel density, but in a contradictory way. The subset of patients without metastases had a higher microvessel density, which is an unexpected result. This leads one to suggest that the result is a casual finding. Another study using a colorimetric messenger RNA in situ hybridization assay for VEGF revealed a positive correlation between VEGF expression and lymphatic spread in penile carcinomas ${ }^{10}$. Perhaps, these controversial results might be explained by differences in the technology employed to access angiogenesis or in the series characteristics.

\section{CONCLUSIONS}

In squamous cell carcinoma of the penis the CD34 expression has no association with tumor grade or stage, as well as with lymphatic spread.

\section{REFERENCES}

1. McDougal WS, Kirchner FKJr, Edwards RH, Killion LT. Treatment of carcinoma of the penis: the case for primary lymphadenectomy. J Urol 1986; 36: 38-41.

2. Theodorescu D, Russo P, Zhang ZF, Morash C, Fair WR. Outcomes of initial surveillance of invasive squamous cell carcinoma of the penis and negative nodes. J Urol 1996; 155: 1626
3. Derakshani P, Neubauer S, Schwarzer U, Klotz T, Engelmann U. Risk-adapted therapy in patients with penile cancer. J Urol (Suppl.) 2000; 163: 638A.

4. Hermanek P, Hutter RVP, Sobin LH, Wagner G, Wittekind C. T,N.M. Atlas, $4^{\text {th }}$ ed., New York, Springer-Verlag, 1999. p. 264.

5. Taylor CR, Shi SR, Chaiwun B, Young L, Iman AS, Cote RJ. Strategies for improving the immunohistochemical staining of various intranuclear prognostic markers in formalin-paraffin sections: androgen receptor, estrogen receptor, progesterone receptor, $\mathrm{p} 53$ protein, proliferation cell nuclear antigen and Ki-67 antigen revealed by antigen retrieval techniques. Hum Pathol 1994; 25: 263-70.

6. Sivridis E, Giatromanolaki A, Gatter KC, Harris AL, Koukourakis MI. Tumor and Angiogenesis Research Group: Association of hypoxia-inducible factors 1alpha and 2alpha with activated angiogenic pathways and prognosis in patients with endometrial carcinoma. Cancer 2002; 95: 1055-63.

7. Orre M, Lotfi-Miri M, Mamers P, Rogers PA. Increased microvessel density in mucinous compared with malignant serous and benign tumors of the ovary. Br J Cancer 1998; 77: 2204-9.

8. Yano T, Tanikawa S, Fujie T, Masutani M, Horie T. Vascular endothelial growth factor expression and neovascularisation in non-small cell lung cancer. Eur J Cancer 2000; 36: 601-9.

9. De la Taille A, Kratz AE, Bagiella E, Buttvan R, Shair S, Olsson CA, Burchardt, Ennis RD, Rubin MA. Microvessel density as a predictor of PSA recurrence after radical prostatectomy. A comparison of CD34 and CD31. Am J Clin Pathol. 2000; 113: 555-62.

10. Slaton JW, Inoue K, Morganstern N, Tamboli P, Ayala A, Dinney CPN, Pettaway CA. Metastasis-related gene expression predicts for positive inguinal nodes in squamous penile carcinoma. J Urol 2000; 163: 641A.

\section{Address:}

Antonio Carlos Pereira Martins

Hospital das Clinicas da FMRP-USP; Departamento de Cirurgia,

Av. Bandeirantes, 3900, Ribeirão Preto, SP, CEP14048-900

e-mail: acpmartins@convex.com.br 